\title{
医薬分業の問題点
}

\author{
早 瀬 幸 俊
}

\section{Problems of the Separation of Prescription and Dispensing}

\author{
Yukitoshi HAYASE \\ Department of Pharmaceutical Administration, Hokkaido College of Pharmacy, \\ 7-1 Katsuraoka-cho, Otaru, Hokkaido 047-0264, Japan
}

(Received December 2, 2002)

\begin{abstract}
By October 2002, the separation of prescribing and dispensing in Japan had already been implemented for 28 years since the system was inaugurated in 1974. Although the separation rate reached $44.5 \%$ in 2001, the questions, "Is the separation necessary in Japan?" or "Has the system been working successfully?" are often heard. These questions are raised because people have not noted the advantages of the system yet, and because the separation itself has many problems or shortcomings. These questions are not only from pharmacists, but also from physicians, patients, or medical and educational institutions. If the problem concerns pharmacists, it is assumed to stem from their lack of ability required for the separation. A breakthrough for an early solution of the problem will be found in a change in education, which includes a range of clinical subjects and long-term clinical practices.
\end{abstract}

Key words_ - problems of separation; separation of prescribing and dispensing; ability required for separation; longterm clinical practices

\section{1.はじめに}

医薬分業は, 欧米では古くから行われており，広 く社会に定着した医療制度としてょく知られてい る。一方，わが国では医薬分業が年々進展している とは言え，その歴史は浅く，いまだ社会全体に定着 した制度とは言えない。このことは医薬分業の実態 を示す処方せん受取率 (分業率) を見ることにより 明らかである。

2001 年度の分業率を, 日本薬剤師会の「保険調 剤の動向」（速報值）で見ると全国平均は $44.5 \%$ (2000 年度：39.5\%) である. 都道府県別では, 分 業の最も進んだ秋田県で 67.6\% (62.9\%), 次に佐賀 県で $63.8 \%(58.9 \%)$ であるが，分業の最も遅れて いる福井県では $13.8 \%(10.8 \%)$, 次に和歌山県では $16.3 \%$ (12.9\%) であり, 都道府県により大きな違 いが見られている.

分業率に関しては, 僻地で保険薬局がないために 医師が処方せんを発行できない場合や, 病院内で薬 を出すほうが患者に対して良い場合などの処方せん

北海道薬科大学薬事管理学研究室 (T047-0264 小樽市 桂岡町 7 番 1 号)

e-mail: hayaseyu@hokuyakudai.ac.jp
が発行できないケースが 20-25\%位あると考えら れているため, わが国では完全に分業が達成された 時の分業率としては 75一 $80 \%$ 位であると言われて いる. この点から考えると, 秋田県や佐賀県では医 薬分業がほぼ達成されつつあるが, 福井県や石川県 ではほとんど分業が行われてないに等しいと言える のではないだろうか.

一方, 韓国では長い間, 医師が診断と調剂を行 い，また薬剤師も患者と相談しながら疾病を判断し て調剤を行ってきた。このため医師側は, 医薬分業 に対して準備段階から強力に反対をしていたが, 2000 年 7 月から強制完全医薬分業が実施された. ${ }^{11}$ 1 年後の 2001 年 7 月でも医薬分業制度は完全に定 着することはなく, 現時点では韓国の医薬分業は失 敗したようであり，石井は2)その原因について医薬 分業の準備期間が「短期」で「強制」であつたから だと述べている.

日本では，処方せん料が 50 点（500 円）に引き 上げられた 1974 年が日本における医薬分業元年で あると言われている. ${ }^{3)}$ それから 27 年間経過した 2001 年度においても依然として都道府県間の分業 率には大きな違いが存在しているが, 韓国における 
分業の失敗原因を考えるとわが国の場合は，任意分 業でそのために時間がかかっていることのほうが分 業の定着のためにはむしろ良かったのではないかと 思われる。

いずれにしても, 近々わが国では完全に医薬分業 が達成されると思われるが，残念なことに，現在で も「医薬分業は本当に国民のためになっているのか」 という言葉を耳にすることがある．これは高い分業 率を示しつつあるにもかかわらず，国民に分業の意 義があまり感じられないことにより発せられた警告 であり, そこには多くの問題点が存在し, その問題 点の解決がさほど簡単ではないと言うことが想像で きる.

長い時間をかけて育ててきたわが国の医薬分業で はあるが，真に必要な医療制度として国民に受け入 れられなければ，この制度の存続が危うくなること も考えられる．そのような事態を将来招かないため には, 医薬分業に関わる問題点を早期に解決し, 早 く国民に支持される制度にすることが重要である.

\section{2. 医薬分業の意義}

医薬分業とは，何であろうか.

中村ら ${ }^{4)}$ は, 「医薬分業とは, 医師が医療上患者 に投薬を必要とした場合に，医師が患者に処方せん を交付し, 患者は薬局にその処方せんを持参し, 薬 局はその処方せんに基づいて調剤し，その調剤され た薬剤を適正指導の元に患者に交付する一連の行為 の総称として用いられている.」としている.

また，吉邨は5)「医薬分業とは，疾病を治療する 行為の中で, 病気を診断し, 治療する医師と, 薬物 療法において薬物を担当する薬剤師が，おのおのの 職能をもとに，より自律的に仕事を分担することに よって，患者に質のよい医療サービスを提供し，医 療に貢献しようとするものである.」と言つている.

さらに福島は3)「医薬分業とは，医療において， 医師が患者の診断，治療を行い，必要な薬剤につい ては，医師が処方せんを作成し，薬剤師がその処方 せんに基づき調剤や薬歴管理, 服薬指導を行い, そ れぞれの専門的な職能を発揮して，国民医療の質的 向上を図ろうとする, 社会的な要求の帰結として用 意された仕組みである.」としている，3 者には言 葉に若干の違いがあるものの，基本的にその内容は 同じであり，これらを端的に言えば「医薬分業と は，医師が直接患者に必要な薬を手渡すことなく処
方せんを交付し，薬局薬剂師がその処方せんに基づ き調剤して患者に薬を手渡す制度」ということにな る.

一方，日本薬剤師会は「医薬分業とは，地域にお いて，医師の処方せんに基づき，薬の専門家である 薬剂師が，処方内容を確認した上で，適正に管理さ れて品質が保証された医薬品を用い，正確に調製し た薬剤を，適切な指導を加えて患者に交付すること によって，医師と薬剤師が専門的な機能で協力し合 い，よりよい医療を患者に提供することを言う.」 とし, さらに「医薬分業とは, 医薬品に関する総て の業務, すなわち, 開発, 製造, 供給, 試験, 管 理, 情報, 調剂, 指導, 相談に至るまでの責任と主 体性を薬剂師が持つことによって，医療の合理化と 医薬品供給の円滑化を図り，国民の健康な生活を確 保するために貢献することを言う.」としている. ${ }^{4)}$

ここで医薬分業の意義を理解しやすくするために 具体的事例を用いてどのようなメリットがあるのか について触れるとともに，医薬分業のデメリットに ついても触れてみたい。

医薬分業のメリットとしては次のようなことが上 げられる. ${ }^{3,6,7)}$

1.「かかりつけ薬局」において薬歴管理を行うこ とにより，複数診療科受診による重複投薬，相 互作用の有無の確認などができ, 薬物療法の有 効性・安全性が向上すること.

2. 薬の効果, 副作用, 用法などについて, 薬剤師 が処方した医師・歯科医師と連携して，患者に 十分な説明（服薬指導）を行うことにより，患 者の薬に対する理解が深まり，調剤された薬を 用法どおり服用することが期待でき, 薬物療法 の有効性，安全性が向上すること.

3. 医師が使用したい医薬品が手元になくても必要 な医薬品を用いて患者に最善の処方が可能とな ること

4. 処方せんを患者に交付することにより，患者が 自分の服用薬を知ることが可能になること.

5. 患者の薬の待ち時間が短縮されること.

6. 病院薬剤師の外来調剤業務が軽減することによ り，本来病院薬剤師が行うべき入院患者に対す る病棟活動が可能となること.

医薬分業によってこのような多くのメリットが期 待されるが，国民を始めとして，医師や薬剤師，看 
護師が互いの立場でこれらの事柄をメリットとして 十分に理解し，活用するとともに，薬剤師や医師， 看護師などがお互いの職能や職域を理解し, 協調 し，尊重し合うことが出来なければ，わが国の医薬 分業が社会制度として定着することは困難になる。

これまで国は，患者 1 人 1 人が自分の薬局である 「かかりつけ薬局」を持つことを推奨してきている. これは医薬分業の進展に伴って患者が複数の医療機 関で受診した場合でも，「かかりつけ薬局」におい て患者の薬歴管理を行うことによりすべての薬が把 握できる結果, 複数診療科受診による重複投薬や相 互作用の有無を確認し, 薬物療法の有効性や安全性 を向上させることができるなどの分業のメリットを 生かすことができる，いわゆる面分業制度を推進す るためなのである.

一方, 医薬分業のデメリットとしては次のような ことが考えられる.

1. 病院などで医師に受診した後, 薬局で処方せん により調剂してもらうため, 患者にとって二度 手間となり不便であること.

2. 処方せん料等の加算により患者の一部負担金が 増えること。

医薬分業をより良い社会制度として定着させるた めには，これらのデメリットを早期に解決すること が重要である.

これまで長い間, 病院や診療所から薬を直接手渡 しされていた患者が，分業により医師に受診した 後, 薬局で処方せんにより調剤してもらうことを二 度手間となり不便と感じることは，ごく自然なこと であろう。しかしながら, 患者が医師からの処方せ んを薬局に持参し, 薬局薬剤師から薬を受け取るこ とは医薬分業の根幹部分である。このため, 薬剤師 は処方せん調剤により薬局から薬を手渡されること の重要性について，患者に十分に理解してもらうよ うに努力する必要があると考えている. 患者が医薬 分業の意義を十分に理解できれば，薬局から薬を受 け取ることを，「二度手間で不便」とは思わなくな るであろうし，むしろ患者は薬局薬剤師を自分の健 康作りの良きパートナーとして身近な存在に感じる ようになると考えている.

一方，現行の診療報酬体系では，医薬分業により 患者の一部負担額が高くなる問題も含まれており保 険制度や診療報酬の改善が求められる。これらを改
善するために考えられることは，すでに米国などで 行われている薬剤師による代替調剂，つまり成分が 同じ薬の場合には薬剤師が患者と相談してより安価 な薬品に替えることや，慢性疾患患者に対して医師 が一度発行した処方せんで 1 年一 2 年間程度繰り返 し調剤することができる，いわゆる「リフィル制度」 などを取り入れることが有効であると思われる. ${ }^{3,8}$

福島は3)これらの経済性を含めた医薬品の適正使 用について, 薬剤師の専門知識がより重要になって きていると述べているが，同感である.

\section{3. 医薬分業の起源}

医薬分業は，いつ，どこで，だれにより行われた のであろうか.

1240 年に神聖ローマ帝国（現在のドイツ）のフ リードリッヒ II 世が制定した下記の 5 カ条からなる 法律を施行した。

1. 医師が薬室を持つことを禁じる．また薬剤師 との共同経営を禁じる。

2. 医師の委員会が薬局を監視する.

3. 薬局の数を制限する.

4. 薬品調整の基準を定める.

5. 薬価計算法を制定する.

このことにより，医薬分業がヨーロッパで始まった とされている. ${ }^{3,4)}$ その後も, この法律に盛り込まれ た考え方が受け継がれ，アメリカやヨーロッパ各国 に医薬分業が制度として定着し，その結果これらの 国の薬剤師は医療の場で薬の専門家としてその職能 が認められるようになつたのである。

\section{4. 日本における医薬分業の歴史}

ヨーロッパにおける医薬分業の歴史は大変に古く, 1240 年に始まったとされているが，これに対して わが国の医薬分業については，いつ，民゙こで，だれ により行われたのであろうか. わが国の医薬分業の 歴史を知ることは，医薬分業の問題点を考える上で も大変に重要であり，これについては福島ら帛が 「社会薬学」に詳述しているので, これを次に紹介 する.

「日本における医薬分業の歴史」(「社会薬学」より抜粋)

日本における医薬分業は 1871 年に政府がドイツ医学導 入を決定した時点に始まる。 ミュルレル及びホフマン は, 政府の招きで来日し, 第 1 大学区医学校（後に東京 大学医学部）の教授となり教鞭に当たるが, 医制度の確 
立をめざして「医制」の起草にも着手した，そして「日 本の医業の隆盛を期するには, 薬学の研究も併せ行い, 医学と薬学を併立して行わなければ立派な医制は確立で きない.」旨の建白を示し，日本における医薬分業思想の 原点となった。 1874 年に 76 条からなる「医制」が制定 されたが，その中で次に示したような条文が設けられ， 医師には調剤権がなく, 完全医薬分業が規定され, わが 国の医薬分業の制度としての始まりとなった.

\section{医制}

第 34 条「調薬八薬舗主, 薬舗主手代及七薬舗見習二 非サレハ之ヨ許サス」

第 41 条「医師タル者八自ラ薬ヨヒサクコトヨ禁又. 医師八処方書 $\ni$ 病家二付与シ相当ノ診料 受クヘシ」

1878 年にも医制で定めた医師の薬剤公布規制を実行さ せるために, 医師の薬舗兼業を自今禁止する令が発布さ れたが, この法令は, 薬舗数の不足のため, 1884 年に解 除された。 1889 年に薬律と呼ばれる「薬品営業並薬品取 扱規則」が制定され, 薬剤師の名が初めて用いられた。 これは薬剤師，薬局の定義など薬事制度の総合的な法律 であった.

薬品営業並薬品取扱規則

第 1 条「薬剤師トハ, 薬局Э開設シ, 医師ノ処方箋二 ヨリ薬剤ヨ調合スル者ヨ言フ薬剤師八薬品ノ 製造及販売ヨ為スコトヨ得」

附則「医師八自ラ診療スル患者ノ処方二限リ $\cdots$ 自 宅二於テ薬剤ヨ調合シ販売授与スルコトヨ得」

第 1 条では, 薬凨師の職能を明確に示しているが, 附 則をつけることで，これまでの慣習を存続させた。この 附則の設定に対して薬剤師側の反発が起こり，本格的な 医薬分業運動が始まった。これから以降，法律の制定 や，法律改正などの際に，医師会と薬剤師会の間で，延 々と論争が繰り返され, 現在にまで至っている.

中でも第 2 次世界大戦以後のアメリカ占領軍統治下の もと, 医薬分業実施について大きな転機と成りうる機会 があった. 1949 年 7 月にダグラス・マッカーサーの招き で，アメリカ薬剤師協会使節団が来日した。これは, 戦 後の新しい社会の構築に合わせて, 医薬分業を実施した いと言う，薬剤師会側の働きかけがあって実現したもの である. 使節団は日本の薬学分野の視察を行い, 日本に おける今後の検討課題として 45 項目からなる勧告書を日
本政府に提出した.

勧告書の要旨

・医薬分業の早期実現に対して可能な限り努力するこ と.

・医師の仕事は，診断，処方せ九発行及び医薬品緊急 投与に限ること.

・開業薬剤師の仕事は, 最も優秀な医薬品を確保し, 適法に貯蔵し，医師の処方せんにより調剤投薬する ことにある。

医薬分業の早急の実現を盛り込んだ勧告書の提出は, 薬剤師側の意気を大いに盛り上げたが，医師側は医薬分 業に反対し，国民をも巻き込んだ大論争となった。 1951 年医薬分業法案が国会に提出されたものの, 結局すぐに は実施されず，1955 年に医師の調剤権を認めた「医薬分 業法の一部改正」が公布され, 翌年から実施されること になり，これが現在にまで至っている，このようにわが 国では，1955 年のいわゆる「分業法」の成立により基本 的な制度として，分業がスタートしたように見る事もで きるが，実際には医師法第 22 条の例外規定により，ほと んど実施されることはなかった。

1974 年 2 月の診療報酬改定により，処方せん料が 6 点 (60 円）から 10 点（100 円）, 10 月の改正で 50 点（500 円）に引き上げられ，現在の医薬分業の流れにつながる スタートポイントとなった. したがって 1974 年は, 日本 における医薬分業の元年であると言われているのである.

以上が日本における医薬分業の歴史である.

約 760 年前から始まったヨーロッパの医薬分業の 歴史に比べてわが国の医薬分業は約 30 年と短く, 医薬分業がわが国の社会制度として定着するか否か のターニングポイントとされていた「処方せん受取 率 $20 \% 」 を$ は経っていないのである.

\section{5. 医薬分業の問題点}

わが国では，医薬分業が本格的に実施されるまで の間，病院や診療所の経営を支える重要な収入源の 1 つとして薬価差益（実際に医療機関に納入された 薬価と保険診療で請求できる薬価との間に差益が生 じていた）があった。これまではこの差益が大きか つたため医師が患者に薬を出せば出すほど収入が増 える図式となり，このことが医薬品の過剰投与を招 く原因ともなり，さらに国民医療費の高騰や医薬分 
業の実施を長期間にわたり阻害する大きな要因の 1 つにもなっていた。

医薬品の過剰投与や国民医療費の高騰を抑制する ための有力な方法として 1974 年に実質的に医薬分 業が実施されたが，新しい制度の本質を国民や医 師，そして薬剤師までもが理解して受け入れるには かなりの時間を必要とした。しかし，国が分業を本 格的に推進するに従い，分業は大きな収益をもたら すことになり，分業を始める医療機関は増加し，こ れに合わせて保険薬局の数も増加の一途をたどっ た．このため, 日本の医薬分業は「経済分業」と挪 揄され，分業上好ましくない種々の問題も発生した のである。このため 1993 年 4 月 30 日付けで当時の 厚生省薬務局長通知として，薬局が果たすべき業務 運営の方針として国が薬局に対して示した「薬局業 務運営ガイドライン」が策定された.

医薬分業が本格的に実施されてから 2002 年 10 月 で 28 年間が経過したことになるが，最近でも「医 薬分業は本当に国民のためになっているのか」とい うような言葉を耳にする。この言葉からも分かるよ うに，医薬分業は現在でもまだ十分に成熟したとは 言えずいろいろな問題点を抱えており，医薬分業を 社会制度として摇るぎないものにするには，これら の問題点の解決が大変重要である.

そこで，これらの問題点について過去と現在に分 けて考えてみたい.

\section{過去における医薬分業の問題点}

1993 年 9 月に出された, 「薬局業務運営ガイドラ イン解説」で，当時の厚生省薬務局の矢野朝水企画 課長が10)「薬局業務運営ガイドラインについて一そ の背景とねらい一」の中で当時の多くの問題点を指 摘しており，これをもとに述べることにする.

「分業は患者のためになっているか」(「薬局業務運営ガイ ドラインについて一その背景とねらい一」から抜粋)

「医薬分業が急速に普及しているのは，民゙うしょうもな い昔の状況を知るものにとってはとりわけ喜ばしいこと であった。しかし分業について詳しく話を聞くにつれ， 何かおかしい，これで果たしていいのか，という疑間が 日に日に強まってきた。長野県上田市の分業は例外中の 例外のようで，第二薬局まがいの門前分業，更にはリ ベート分業（薬局が処方せんあっせんの見返りに医療機 関にリベートを支払う）も少なくないと言う。これで果
たして患者のためになっているのか.

そもそも分業の意義は何か，については様々のことが 言われているが，その本質は医師の処方に対し薬剂師が チェック機能を働かすことではないか，それにより薬の 適正使用を徹底し，医療の質の向上を図ることにある。 薬をより多く出したほうが医療機関の利益が上がるとい うシステムでは，医療不信は解消しない．

このような考えからするとリベート分業は言語道断だ し, 薬歴管理, 服薬指導, 医師に対する疑義照会等の薬 剤師としての本来の業務を果たしていない分業は患者の ためになっていないと言わざるを得ない.

休日, 夜間の応需といった不採算部門からは逃げ，も うかる部門しかやらないと言うのでは医療の公共性, 薬 剤師の使命を無視することになる.

以上のように患者のためにならない医薬分業なら，い ずれ必ず国民の反発を招くし，やらないほうがましとさ え言えるのではあるまいか。医薬分業は理念としては優 れているのであるから，その理念が実行面でも生かされ なければならない，おかしな分業が全国に蔓延しないよ う今のうちに歯止めをかけておく必要があると痛感した のである.」

当時の長野県上田市は, 分業が最も進んだ場所と してよく知られていた。このころ私は上田市の薬剤 師との話のなかで，上田市の患者は各自が「かかり つけ薬局」を持っており診察を受けた医療機関から 「かかりつけ薬局」が遠くても，処方せんを持参す ることを知った。 上田市は, 単に分業率が高いだけ でなく，面分業の点でも先進地であったのである. 本来, 医薬分業は患者の薬物治療を適切に行うため の制度であり，このためにも「かかりつけ薬局」を 持つことは大変重要なことである。しかし, 医療機 関から直接薬を受け取ることに慣れた当時の患者に してみれば，診察を受けた医療機関の近くの薬局の ほうが早く薬を受け取ることができて便利と感じる のは当然かも知れない.

現在でも「かかりつけ薬局」を持たず，いわゆる 「門前薬局」で調剤してもらう患者がまだ数多くい ることは否定できない事実である。この点で，上田 市の住民は医薬分業当初から国が進めていた「かか りつけ薬局」を持つことを全国に先駆けて実行して いたのであるから驚きであるが，このような住民の 育成は日頃からの上田市の薬剤師の活動による成果 と思われる。 
当時の上田市で行われていた医薬分業は本来の分 業のあるべき姿であるが，矢野は「長野県上田市の 分業は例外中の例外のようで」あり,「第二薬局ま がいの門前分業，更にはリベート分業も少なくな い」という問題点を提起している.

「第二薬局」とは，医療機関の親族などが医療機 関の敷地内あるいは隣接地に開設した保険薬局のこ とであり，医療機関内の薬局を第一薬局としたと き，医療機関外に開設した薬局という意味合いで第 二薬局と呼んでいたようである.

第二薬局誕生の理由は, 単に医療機関が外来患者 に対して院内で調剤して薬を渡すより, 第二薬局で 患者に薬を渡したほうが処方せん発行料を稼ぐこと ができるためである. 分業当初によく見られた第二 薬局ではあるが医薬分業の目的に沿わないために問 題となり, その後法律が改正されて医療機関の親族 などが直接に保険薬局を開設することはできなくな つたのである. 第二薬局まがいの門前薬局を開設さ せないために薬局業務運営ガイドラインの中にも, 「薬局は医療機関から経済的, 機能的, 構造的に独 立していなければならない」との規定がある。

矢野が指摘した「第二薬局まがいの門前分業」に ついては, 表向きには医療機関の開設者・親族が経 営しているとは分からない門前の保険薬局を指すも のと想像している.

「リベート分業」については分業当初から行われ ていたようで, 1993 年の薬局業務運営ガイドライ ンの中でもリベート分業につながるものとして「薬 局は医療機関と処方せんの斡旋について約束を取り 交してはならない」と規定している.さらに「薬局 は医療機関に対し処方せんの斡旋の見返りに, 方法 のいかんを問わず, 金銭, 物品, 便益, 労務, 供応 その他経済上の利益の提供を行ってはならない」と 明確にリベート分業をしないように再度規定してい る.

このことについては天野が11)「薬の倫理」の中で 以下のように詳細に述べている.

「大手チェーン調剤薬局のリベート事件」(「薬の倫理」よ り抜粋)

「平成 7 年（1995 年）から 8 年にかけて, 大手調剤専 門薬局が院外処方の見返りとして医療機関側に謝礼を贈
つていたという事実が新聞紙上をにぎわした.

平成 7 年 11 月 25 日付の朝日新聞は「東京を中心に 88 店舗をもつ調剂薬局最大手の会社が，その年の 4 月に店 頭公開された株式の未公開株を薬局の近くにある病院の 医師らに譲渡していた」と報じている。この株価は公開 直後, 譲渡価格の約 10 倍に值上がりしており, 院外処方 せん発行に対する事実上のリベートとしてみられている と分析している. さらに, この会社は大学病院の職員や 家族の薬代のうち自己負担分を肩代わりしていたことも 明らかになった．全面分業に移行する前は病院が職員ら の自己負担分を減免していたが, 門前薬局に変わったた め，それを調剤薬局が肩代わりしたと言うのである.

さらに，翌年の 3 月，調剤薬局第 2 位の会社が 7 医療 機関に医薬分業の薬価差として総額 3 億円以上にも上る 補填を行っていたことが明るみになった． 3 月 2 日付の 朝日新聞によると「この調剤薬局は毎月の処方せん枚数 などに応じて北海道や東京などの 7 病院, 医院に対して リベートとして少なくとも 3 億円以上が支払われてい た.リベートには病院が医薬分業に踏み切る前に得てい た薬価差益などを補填する意味合いがあり, 薬局間の競 争を勝ち抜くために病院側の要求を受け入れていたと言 う」と報じている。この 2 つの調剤薬局で露呈した問題 は, 分業が病医院, 薬局間の経済的な面で結びついてい たと言うことである。ここで考えさせられることは, 病 医院などの医療機関の関係者, 及び薬局側が倫理観を持 ち合わせていたかどうかと言うことである. 確かに経済 的な問題は病医院の経営, 調剤薬局の経営に及んでくる ことは事実であるが，医薬分業はあくまで患者を中心に 考えるべき問題である. 地域に根ざした薬局こそが求め られており，そこに本来の医薬分業が進んでいくはずで ある. 医療機関の関係者, 薬局の薬剤師らの大多数は薬 の倫理を持ち合わせていると思われるが, 薬を商いの手 段に使う一部の人たちが, 今回のような不祥事を起こし たと考えられる.」

このようにリベート分業が，薬局業務運営ガイド ライン発表後も 1996 年まで行われていたことは大 変な驚きであったが, ここに紹介されたリベート事 件は「大型チェーン調剤薬局のリベート事件」とい うことで特に社会に目立つたものであり，この他に も規模の小さなリベート分業がある程度行われてい たのではないかと思われる.

このような事件が明るみに出たことにより，保険 薬局が医療機関からのリベート請求をきっぱり断る 
きっかけとなり，また医薬分業を本来のあるべき姿 に戻す上で多いに貢献してくれたと私は考えている.

また，前述の矢野の指摘の中にある「休日，夜間 の応需といった不採算部門からは逃げ，もうかる部 門しかやらないと言うのでは医療の公共性, 薬剤師 の使命を無視することになる」とのことは，当時の 保険薬局や薬剂師の医薬分業に対する姿勢を垣間見 るようで興味深い. 1992 年の医療法の改正により 薬剤師は晴れて医療の担い手の一員であることが明 確に規定されたのであるから，医療人としての自覚 を持てば，「休日，夜間の応需といった不採算部門 からは逃げ，もうかる部門しかやらない」と言うこ とにはならないはずである. しかし，残念ながら薬 剤師は法律で「医療の担い手の一員」になっても, 一夜にして医療の担い手としての倫理観や使命感を 持つことはできなかつたようである。薬局に課せら れた医療の公共性や薬剤師に医療人としての使命感 が求められているとは言え, 日常の業務も含めて薬 局経営が成り立たなければ，休日，夜間に応需する ことが困難となる薬局が存在することも残念ながら 事実である。

現在は，休日の応需に関しては多くの地域の薬剤 師会が中心になり担当薬局を順番制で決めて対応し ている，また，夜間の応需に関してはほとんどの保 険薬局で夜間担当薬剂師が携帯電話等を持つなどし て患者に対応できるようにしており，この問題はか なり解消されつつあると思われる.

さらに矢野は次のような指摘もしている.

「医療保険制度の動向」(「薬局業務運営ガイドラインにつ いて一その背景とねらい一」から抜粋)

「わが国は国民皆保険で，医療費は原則保険制度でまか なわれている. 分業も保険制度の枠内の話であるから保 険制度の動向に大きく左右されることは言うまでもな い。 そもそも分業が伸びるようになつたのは昭和 49 年 （1974 年）に処方せん料が一挙に 5 倍に引き上げられた のが契機になっている. 医療保険サイドの支援策がなけ れば分業は進まない.

他方, 医薬分業は薬の適正使用を進めるためのシステ ムであり, 経済問題を直接のターゲットとするものでは ない。しかし，分業により医師が薬を使用するにあたつ て経済的インセンティブがなくなれば, 薬の使用量が減 ることが見込まれる．特に欧米に較べ患者 1 人当たりの
薬の使用量が 2-3 倍も多いと言われているわが国にあっ ては, 分業は薬の使用量の減少を通じて保険財政にもプ ラスになるとの期待が保険サイドにはあると思う.

このような保険サイドの期待に分業は応えているのだ ろうか.このような期待に分業が応えられないと言うこ とがはっきりすれば分業はどうなるのか. もつとドラス ティックな医薬品抑制策がとられ, 分業に対する支援策 は転換される可能性があるのではないか，第二薬局まが いの分業やリベート分業のようなことをやっていては, 高齢化時代の医療保険制度改革の大きな波に分業は吞み こまれてしまう恐れさえある。

もともと薬剤師は薬の貢任者であり, 薬の効率的な使 用についても無縁ではすまされない，患者本位の良質の 医療サービスを提供することによって医療保険サイドの 理解と協力が得られるよう, 絶えず努力していく必要が ある. そのためにも薬局業務の適正な運営が求められて いる.」

医薬分業は薬の適正使用を進めるためのシステム であり, 経済問題を直接のターゲットとするもので ないことは誰しもが認めるところであろう。しか し, 欧米に較べて患者 1 人当たりの薬の使用量が 2 -3 倍も多いと言われている状況に何ら問題はない のであろうか.わが国の国民医療費に占める薬剤費 の割合（薬剂比率）は，1975 年一1993 年では 29.5 -38.7\%の間で推移している。これを 1993 年の デー夕を用いて国際比較すると, 日本 $29.5 \%$, フ ランス $19.6 \%$ ，ドイツ $17.1 \%$ ，イギリス $16.4 \%$, アメリカ $11.3 \%$ の順となっており, ${ }^{12)}$ 日本での薬の 使用量が欧米に較べて約 1.5-2.6 倍多く, 他国に 比して薬漬け医療の行われている実態が明らかとな つた.

当時，毎年国民医療費が約一兆円ずつ増加する状 況が続いており，近い将来において医療保険制度が 財政危機により立ち行かなくなるとの危機感が生ま れていた。 保険制度の崩壊を防ぐ手段の 1 つとして 薬剤比率を欧米並夕に低下させることが求められ, その手段として医薬分業が有効であるとされた。し かし, 分業当初はこれまで述べてきたような「第二 薬局まがいの分業やリベート分業」などが行われ, 残念ながら分業による薬剤比率の低下は見られなか つた．このため分業を本来の姿にするために，薬局 業務運営ガイドラインが 1993 年 4 月に当時の厚生 
省薬務局長により通知として出されたのである.ま た，医療関係法規の改正とも相俟って，薬剤比率は 1994 年には $29.5 \%$ から $27.2 \%$ に減少し, 1995 年に は $28.0 \%$ に一時上昇したものの，その後は 1996 年 $(25.9 \%), 1997$ 年 $(24.9 \%), 1998$ 年 $(21.6 \%)$, 1999 年 $(20.8 \%$ ） と順調に低下し，2000 年には $20.1 \%$ と 1993 年のフランス並に低くなり, わが国 においても分業の成果がようやく現れ始めたように 思われる。

これまで触れてきた「過去における医薬分業の問 題点」を通して, 問題点には「分業の制度に関わる 問題点」のように制度の成熟に伴って解決されてい くものと，「人の資質や性質などに関わる問題点」 のように簡単には解決できないものの 2 つが存在し ているように思われた。

\section{現在の医薬分業の問題点}

初めに実務に携わつている薬局薬剂師が，「現在 の医薬分業の問題点」についてどのような考えを持 つているのかを知ることにした.

2002 年 9-10 月に北海道薬剤師会小樽支部（小 樽）と東京都薬剂師会立川支部（立川）で行つたア ンケートの調査用紙の中に「医薬分業に対する問題 点を気軽にお答え下さい（何でも結構です）」とい う項目を設けて行った。 なお, 2001 年度の小樽と 立川の医薬分業率はそれぞれ $55 \%$ と $72 \%$ と違いが 有るものの, 共に全国平均以上の高い值を示してい た.

医薬分業に対する間題点：小樽

1. 発行医療機関（特に広域）と薬局間の連携が, あま りよくないケースが多く, 服薬指導の繁雑さや, 調 片過誤の原因になっている事があると思う.

2. 医薬を分けることで, 本来, 患者さんにあるべきメ リットが, 感じられない。

3. 薬剤師の絶対数が足りなさすぎる.

4. 病院又は処方医の先生方と, ささいな事でも連絡し 合えたり尋ねたりできるようになればいいと思う.

5. これから, 後発医薬品も大変多くなると思うので, 在庫の山にならないようにしたい。

6. 病院で「お話しをしてきているので」と言うことで, 薬局であまり答えてくれない人には, 病状を聞くた めに大変気を使わなくてはならない.

7. 国の医療政策に一貫性がなく, いろいろ変わるので
患者さんも我々も戸惑ってしまう。

8. 病院側とお互いが，やり易くできるような話し合い の場, 時間が欲しい.

9. 薬学部で, 薬剤師教育が余りにも不完全だつた. 実 地研修もなく医療現場に出されている. その不利益 を国民が負っている.

10. 面分業が進んでいないと思う.

11. 広域病院と調剤薬局との連携が，いまひとつ足りな いようだ.

12. 医師を始め, 病院職員との意思疎通がもっとうまく いけば良いと思う。

13. 薬の量が増える. 必然的に, デットストックが多く なってしまう。

14. 病院は薬の規格をきちんと明記して欲しい.

15. ある程度の患者の病名が分かればと思う。

16. 調剂拒否の薬局の話が出る都度, 全薬局に迷惑がか かるので, 誠意ある対応をして欲しい.

17. 見にくい処方せん，不備のある処方せんに困ってい る.

18. 土曜日曜等に, 医療機関から処方せんが発行された 揚合，困る患者さんが出ている.

19．面分業を達成させるためには，同効薬の投薬を原則 的に認める事が必要（一般名処方でも良い）.

20. 分業率が高くなるにつれ, 備蓄薬剤が多くなり, 後 発品まで対応できなくなってきている.

21. 自己負担が多くなってきて, 病院と薬局で支払い, 二重払いのように感じている人もいる.

医薬分業に対する間題点：立川

1. “早く作ってくれ”という患者が多く, 質問（病状） もままならない.

2. 医師，患者，薬剤師間の連携が十分に取れていな い.

3. 法令改正が多すぎて調剤に集中できなくなります。

4. 処方医が保険外の日数を記入したりすることがある 場合，疑義照会しても変更に応じてもらえないよう なケースが出現することがある.

5.一度疑義照会して変更になったにもかかわらず，再 度前と同じ内容で処方されてくる。

6. 後発品の使用が増えるとすぐに少数の薬品を入手し にくいため, 患者さんが薬局をぐるぐる回る事にな る.

7. 医師より服用を患者に“自分で調節して”と言われ たそうで (患者が) 薬局側は処方せんの指示通りの 
服薬説明をした際，医師の“説明と違う”と言われ 困ることがある.

8. 現在, どのような医師に対しても気軽に疑義照会が できない状況である.

9. 各薬局ごとに患者の支払う金額が異なるのは問題で す。

10. 制度が変わつたため, 患者さん（老人）の負担金が 以前より多くなってしまったこと。

11. 在庫が毎年確実に増えすぎて利益率が下降線です。

12. 薬の種類が多く在庫管理が大変です.

13. 処方名を一般名で記すことを原則として, 銘柄は患 者さんと相談して選ぶ方法があれば，デッドストッ クが少なくなり助かります。

14. デッドストックや期限切れについて, 個人店では対 応に限界があります。

15. 長期投薬が可能になり，在庫量が増えて大変です．

16. 完全な面分業のため, 常に薬の在庫に悩んでいます.

17. デッドストックが多くなったことや代替調剤ができ ないこと。

18. 今後, ゾロ品の多用で薬の備蓄が多種多剂に及ぶこ と.

19. 小規模な薬局が，面で処方せんを受けると薬の品目 が増えていくので困る.

20. 薬の在庫がなく, すぐに薬をお渡しできないことが ある。

21. 特に日曜日, 土曜日などに薬が揃わず患者さんに迷 惑をかけることがある.

22. 何度も同じ疑義照会を行わなければならないケース がよくある。

23. 処方せん発行日の翌日以降に持参した時, 疑義があ るのに医師が不在の時の対応が問題.

24. 例えば，抗がん剂の処方せんを初めて受けた場合， 告知を受けているのかどうか, 休薬期間があるのか どうかなどが，手さぐりとなること.

25. 処方せんが正確に記入されていない場合がある.

26. 手書きの処方せんでは字が読めない場合がある.

27. 医師の処方意図が理解しにくく, 服薬指導に支障を 来すことがある.

28. 面分業が進むにつれ, 顔も知らない医師からの処方 せんを受けることが多くなって来た。本来ならば, 処方医の考え方や人間性, コンセプト等の背景も知 りたいところである.

29. かかりつけ薬局と言つてはいるが, 実際門前薬局の
ほうが備蓄漏れがないため門前薬局で調剤を受ける 患者がまだまだ多い.

これらの結果から，アンケートの回答の内容には 地域差や分業率の差による違いは特に見られなかっ た. しかし, 分業初期からの問題点と思われるよう な回答も散見されており, わが国の医薬分業を本来 のあるべき姿にするためには, かなりの時間が必要 であると思われた。

以後，アンケートの結果も踏まえながら「現在の 医薬分業の問題点」について 1) 薬凨師，2）医師 との関係，3）国民・患者との関係，4）医療制度,

5）薬学教育の各項目に分けて述べてみたい.

\section{1) 薬剂師}

医薬分業が本格的に始まった 1974 年度から 15 年 経過した 1989 年度の分業率は $11.3 \%$ とまだかなり 低い数值を示しており，この間に分業はあまり進展 しなかったことが窥える。これに対して，1989年 度から 1995 年度の 6 年間に分業率は $20.3 \%$ と 1989 年度の約 2 倍に伸び, 1995 年度から 2001 年度の 6 年間には $44.5 \%$ と 1989 年度の分業率の約 4 倍に急 激に伸びた，そしてこの分業率の急速な伸びが，薬 剤師に関わる種々の問題を引き起こす原因の 1 つに なったものと考えている.

つまり, 薬局（薬剂師）は長い間，一般用医薬品 や化粧品, 衛生用品などを販売し, 処方せん調剤の 機会はほとんどない状態であった。このため,この ような薬局（薬剂師）の一部には急激に分業が進展 しても今まで通り一般用医薬品や雑貨などを販売し 続けて，積極的に分業には参加しない，あるいは， 参加できない者も現れた。このような薬局 (薬剤師) では, 取り扱う医薬品の種類や量が一般的に少な く, 結果的に調剤拒否をしたり, また一般用医薬品 や雑貨などの販売とは異なる能力が調剤業務には必 要とされるがこれに十分対応できず，この結果とし て意識の低さやレベルの低さを指摘されるに至った ものと思われる.

この他に意識やレベルの低さを指摘される薬剤師 が存在する原因の 1 つとしては, 近年の急激な分業 率の伸びに起因する薬局数の増加による極端な薬剤 師不足のため, これまでは薬剤師として働くことが 考えられなかったような人達までもが，薬局薬剤師 として働く機会を簡単に得られるようになったこと 
もあると考えている.

現在, 薬剤師にはどのような能力が必要とされて いるのであろうか. 薬局薬剤師から教授された必要 とされる能力の一部を次に示した.

「医師等の処方の内容を理解して適切な剂形で正 確，安全，迅速に調剂する能力」

「薬物療法の目的, 方法, 効果及び薬剤の安定性 に関して患者に適切に説明する能力」

「患者の病態や背景等を踏まえて投薬の方法と服 薬条件等を適切に説明する能力」

「薬物療法に関して医療従事者等に適正な情報提 供を行う能力」

「専門の情報や文献を検索, 評価し, 薬物療法向 上のために利用する能力」

「コンピュータ技能及び技術の進歩を実務に適用 する能力」

「薬物療法及び薬学的ケアの成果を評価し, 文書 で報告する能力」

「処方及び投薬に関して疑義があれば医師に照会 する能力」

「個々の治療計画の状況及び予期される治療の結 果に関して薬学的評価を行う能力」

「患者の状況を踏まえ, 投薬及び検査を助言する 能力」

「医薬品間及び医薬品と食品・嗜好品間の相互作 用を的確に把握し，説明する能力」

「有効かつ安全で効率の良い薬学的ケアを行うた め薬物療法を経時的に評価する能力」

「医薬品等に関わるリスクマネジメントを適切に 行える能力」

「保険制度を理解し薬剤師として医薬品の適正使 用に貢献する能力」

「薬歴等を踏まえ, 適切に一般用医薬品を選択で きる能力」

「医薬品等に関する最新の法規や規則を理解し, 適切に医薬品などを保管・管理し供給する能力」

保険薬局薬剤師に必要であると考えられる能力の 一部を示したが, わが国の大半の薬科大学や大学薬 学部では, 残念ながらこれらの能力を十分に養成す るための教育は行われていないと考えている.この ために，これらの能力の一部が欠落した資質の低い 薬剂師が数多く薬局に勤務していると言うことも医
薬分業の問題点である．ましてや，数十年前に薬学 を学んだままの薬剤師免許取得者が，薬局に勤務し てすぐに調剂業務を行うことは困難なことと思われ るが，薬剤師不足のためにこのような薬剤師が薬局 に勤務していることも事実なのである.

また，薬局薬剤師と病院薬剂師とのいわゆる「薬 薬連携」に関してであるが，連携が良く取れている 地域もあるが，取れていない地域もあるようで，こ のことも問題点の 1 つとして挙げることができる. これは，長期間にわたり病院薬剂師と薬局薬剂師と で薬剤師業務の内容が大きく異なっており, 日頃か らお互いに業務上のことで交流する機会がほとんど なかったことに起因しているものと考えている.

今後は, 分業や在宅医療などの更なる進展に伴 い，患者情報を互いに共有あるいは補完することが 必要になると思われ，その点で「薬薬連携」は大変 重要になると考えており，日頃から互いに意思の疎 通を図るように努力する必要がある.

\section{2）医師との関係}

医薬分業は医師に対しても大きな変化を求めるも のになった．分業前までは，自分の考えで薬を自由 に患者に手渡すことができたが，分業後は薬剤師に 処方をチェックされ，薬も自分で直接患者に手渡せ なくなつたのであるから医師の側にも大きな戸惑い があったと思われる。また，これまで日常的に医師 と係わりを持つことのほとんどなかつた薬荗師が, 医薬分業により患者を通して医師と係わりを持つこ とになり, 手探り状態で始めた医師への対応には少 なからず困難なこともあったようである. 1997 年 4 月から施行された薬剤師法第 25 条の 2 (情報の提 供）は，医薬分業の下で薬剂師の職能を発揮させる ための法律と考えられた。しかし，この情報提供に 関しては分業の先進地である長野県上田市で薬剤師 が情報提供を行った結果，副作用を心配した患者が 薬を飲むことに不安を覚えて医師に訴えたことによ り，医師会から「薬剤師の情報提供が医師の診療行 為を妨害しており, 処方せんの発行停止も考えざる を得ない」とする見解が出されるという出来事が起 こったのである. 医師と薬剤師の関係が良いからこ その分業先進地と考えていた上田市で起こったこの 出来事はいかに薬剤師が医師と連携を取ることが難 しいかを教えてくれた。しかしその反面，患者に対 してより良い医療を行うためには日頃から意思の疎 
通を図り医薬連携を十分に取るように努力する必要 があることを教えてくれた出来事でもあった.

いろいろな状況から判断し, 現在でも医薬連携は 総じてまだ十分とは言えないと考えている. 医薬分 業を成熟させるためにも, 診療所の医師のみならず 広域病院の医師とも医薬連携が十分に取れるように 努力する必要があると思われる。

\section{3） 国民 - 患者との関係}

分業率が高くなつた現在でも薬局薬剤師と話をし たがらない患者がいることを耳にする，しかし，薬 剤師に話をすることが患者にとって有益と実感すれ ば，多くの患者は薬剤師に積極的に話をしてくれる ことも事実である、薬剤師に話をしたがらない患者 に話をしてもらうようにすることは, 薬剤師の大切 な仕事の 1 つである. 患者と十分に話をしなけれ ば，いつまで経っても薬剤師の職能は理解してもら えないのである.

ところで, 薬剤師の仕事の内容について国民には どの程度理解されているのであろうか. 薬学関係者 や薬剂師が想像しているほどには, 国民は薬剤師の 仕事を理解していないのではないだろうか. 薬剤師 が国民にとって存在感の薄い医療人であるなら, 医 薬分業は薬剤師の存在感を高めるためには絶好の機 会である. 薬剤師 1 人 1 人が誠実かつ積極的に国民 に対し, 粘り強く医薬分業の意義と薬剤師の職能が 患者に有益であることを伝えるべきである. さもな ければ，いつでも「医薬分業不要論」が声高に出て くることを覚悟しなければならないと思われる.

今後，真に分業を進めるためには，国民と薬剤師 個人とが信頼関係を築くことが必要であり，そのた めには「かかりつけ薬剤師」制度の推進が有効であ ると考えている。

\section{4) 医療制度}

医療制度が変更されるとすぐにそれに対応しなけ ればならない薬局が, 種々の問題を抱えることは自 然なことであるが，制度に関わる問題は法律であ り, 場合によっては薬局自身では解決不可能なもの が含まれる場合があるので厄介である.

例えば，2002 年 4 月より保険財源の節約の観点 から後発品を使うように国が働きかけた結果，「ゾ 口品の多用で薬の備蓄が多種多剂に及ぶ」「後発品 の処方せんには, 少々困っている」「後発品は入手 困難なものが多く, 包装単位も大きく困る」などの
問題点がでてきた。 また, 老人保健制度の変更に伴 い支払い金額が増える場合や，薬の数が増えても支 払金額が減る場合など老人にはなかなか理解しにく いケースがこれまでにあり, 制度変更の度に患者に 理解を得るのに苦労しているようである.

また薬剤師にとつては，制度が変われば瞬時に新 たに必要な知識の吸収が要求されるが, 実務上の実 施方法が十分に明らかにされないまま制度がスター トすることも珍しくなく, 短期間の制度の変更の繰 り返しは国として必要でも, 国民や医療現場には大 きな負担と混乱を招くことになり問題となる.

今後は長期展望に立つた制度の運用を目指して, 可能な限り短期間での変更を避け, 変更する場合は 時間的余裕を持って変更点を周知徹底させた後に変 更することが必要であると思われる.

\section{5) 薬学教育}

教育は薬剤師の能力と深く関わつていると言う点 で多くの問題を含んでいる.

長い間, 薬学部では製薬メーカーで薬の研究開発 に携わる研究者やMR (Medical Representative) の 養成を中心とした教育が行われ，臨床教育はほとん ど行われてこなかつた。つまり，「薬」という物質 中心の教育だけが行われていたが，この薬学教育の 内容が社会的に問題になることはほとんどなく，む しろ, 薬剤師教育は就職先の薬局や病院で行うもの との考え方をしていたようである.

薬局が一般用医薬品や雑貨などを販売していた時 代には，このような物質教育を受けた者でも薬剤師 として務まったのである.しかし，1）薬剤師の項 で示した医薬分業で必要とされる薬剤師の種々の能 力は, 個人の努力や薬局, 病院等の職場で働きなが ら獲得できる範疇を既に大きく超えていると考えて いる.このため, これらの能力を獲得するには, 大 学薬学部で系統立てた教育を行う以外に方法はない のであるが, 残念ながらこれらの能力が獲得できる 教育をしている大学は既述したようにほとんどない し, 4 年間の座学中心の教育では所詮無理である. このため医薬分業の進展と薬剤師業務の高度化に伴 い薬剤師の質の低さが問題になってきたのである.

この問題の解決の方法は大学における臨床教育と 薬局や病院などにおける長期間の臨床実習の充実で あり早期の実現が望まれるが，一方これらの臨床教 育を担当できる教員数が少ないのも大きな問題であ 
り，早期の解決が望まれるところである.

6. おわりに

医薬分業は国民のための医療制度であるが，これ を支える薬剤師や医師がこの制度を真に国民のため の制度として認識しているかは疑問である。なぜな らば，これまで述べてきたように医薬分業にはまだ 多くの問題点が存在するからである. また, 「過去 と現在」,「分業率の高い地域と低い地域」「都市部 と過疎地」,「制度の変更前と変更後」など状況の違 いにより問題点の解決方法も異なると思われる。い ずれにせよ, 薬剤師が関与する問題点については早 期の解決が望まれる.

現在，薬剤師はその資質において問題があると言 われている。薬剤師資質の向上は医薬分業の充実の ために避けて通れない問題であるが，これに関して は薬科大学や大学薬学部の教育が密接に関わつてい る重要な問題である。このため近年，大学における 薬学教育を変革することが社会から強く求められて いるのである.

例えば，「患者さんと十分にコミュニケーション ができる」，「情報を的確につかめる」「情報を的確 に患者や医師, 他の薬剤師に伝えられる」「問題意 識が持てる」「問題が解決できる」「疾病の知識が十 分ある」「薬物療法の知識が十分ある」「コンピュー 夕技能や技術が十分ある」等のどれか 1 項目でも欠 落していた場合, 薬剤師として薬局に勤務するには 問題があると思われる。しかし，これまで行われて きた薬学教育では, 臨床教育の内容があまりにも貧 弱であり, 薬剤師が臨床現場で必要とされるこれら 一部の能力でさえも十分に教育することはできてい ないと考えている.

薬剂師が関わる医薬分業の問題点の解決には，早 急に臨床薬学教育の充実を図り, 薬剤師の資質を向 上させることが必要であり，また薬剤師資質の向上 は必ずや薬剤師の地位の向上に繋がるものと考えて いる.

\section{REFERENCES}

1) Kinn K., Abstracts of papers, the 5th Symposium on Clinical Pharmaceutical Sciences in Community Pharmacy, Tokyo, July 8, 2001, p.16.

2) Ishii K., "Pharmaweek," Jiho Co. Ltd., 8056, October 28, 2002, p. 2.

3) Fukushima N., Morita S., Mori S., Ookubo K., Nagamine S., Shiobara Y., Hayase Y., Shigehisa A., Matsuya J., Miura I., "Shin Kusuri to Shakai to Hou," Houritsubunkasha Co. Ltd., Kyoto, 2002, pp. 8-13.

4) Nakamura K., Komiya H., Shiragami M., "Yakujikankeihouki manuaru," Nanzando Co. Ltd., Tokyo, 2002, p. 10.

5) Koyama Y., Fukushima N., Yoshimura T., Yanagawa C., Funaki K., Terada K., Matsuyama K., "Iryouyskugakusouron," Asakurashoten Co. Ltd., Tokyo, 1999, p. 36.

6) Shiobara Y., "Yakujikankeihouki • Seido -Kaisetsu-," Hirokawa Publishing Co., Tokyo, 2000, p. 246.

7) Yakujihourei-iinkai, "Shin-gaidorain Yakujikankeihouki • Seido Kaisetsu, 2nd ed.," Hirokawa Publishing Co., Tokyo, 1997, p. 76.

8) Kamei M., Onda M., Shiragami M., Abstracts of papers, the 12th Annual Meeting of the Japanese Society of Pharmaceutical Health Care and Sciences, Fukuoka, October, 2002, p. 240.

9) Fukushima N., Matsumoto K., "'Shakaiyakugaku, 7th ed.," Division of Social Pharmacy, Kyoritsu College of Pharmacy, Tokyo, 2002, pp. 53-54.

10) Yano A., "Yakkyokugyoumuunei-gaidorain," ed. by Japan Pharmaceutical Association, Yakujinippo Ltd., Tokyo, 1993, pp. 1-7.

11) Amano H., "Kusuri no Rinri," Nanzando Co. Ltd., Tokyo, 1998, pp. 139-141.

12) Iryouhokenseidokenkyukai, "Medemiru iryouhokenhakusho," Gyosei Co. Ltd., Tokyo, 2002, pp. 164-173. 